\title{
Federal Reserve Lending to Troubled Banks During the Financial Crisis, 2007-2010
}

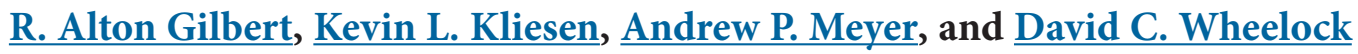

\begin{abstract}
Numerous commentaries have questioned both the legality and appropriateness of Federal Reserve lending to banks during the recent financial crisis. This article addresses two questions motivated by such commentary: Did the Federal Reserve violate either the letter or spirit of the law by lending to undercapitalized banks? Did Federal Reserve credit constitute a large fraction of the deposit liabilities of failed banks during their last year before failure? The Federal Deposit Insurance Corporation Improvement Act of 1991 (FDICIA) imposed limits on the number of days that the Federal Reserve may lend to undercapitalized or critically undercapitalized depository institutions. The authors find no evidence that the Federal Reserve ever exceeded statutory limits during the recent financial crisis, recession, and recovery. In most cases, the number of days that Federal Reserve credit was extended to an undercapitalized or critically undercapitalized depository institution was appreciably less than the number of days permitted under law. Furthermore, compared with patterns of Fed lending during 1985-90, the authors find that few banks that failed during 2008-10 borrowed from the Fed during their last year prior to failure, and even fewer had outstanding Fed loans when they failed. Moreover, Federal Reserve loans averaged less than 1 percent of total deposit liabilities among nearly all banks that did borrow from the Fed during their last year. It is impossible to know whether the enactment of FDICIA explains differences in Federal Reserve lending practices during 2007-10 and the previous period of financial distress in the 1980s. However, it does seem clear that Federal Reserve lending to depository institutions during the recent episode was consistent with the congressional intent of this legislation. (JEL E58, G01, G21, G28)
\end{abstract}

Federal Reserve Bank of St. Louis Review, May/June 2012, 94(3), pp. 221-42.

$\mathbf{T}$ he Federal Reserve responded aggressively—some argue too aggressively—to the crisis that enveloped the world financial system in 2008-09. Using powers granted by legislation enacted during the Great Depression, the Fed established several special lending facilities to (i) provide liquidity to the commercial paper market, money market mutual funds, and investment banks and (ii) facilitate orderly resolution of two large troubled financial firms (Bear Stearns and Co. and American International Group). In addition to providing billions of

R. Alton Gilbert is a visiting scholar and economist emeritus at the Federal Reserve Bank of St. Louis. Kevin L. Kliesen and Andrew P. Meyer are economists and David C. Wheelock is deputy director of research at the Federal Reserve Bank of St. Louis. The authors thank Jane Anne Batjer, Paul Butler, Hillary Debenport, Lyle Kumasaka, Kim Nelson, Julie Stackhouse, and Kristina Stierholz for valuable discussions and assistance in obtaining data used in this project. David A. Lopez provided research assistance.

(c) 2012, The Federal Reserve Bank of St. Louis. The views expressed in this article are those of the author(s) and do not necessarily reflect the views of the Federal Reserve System, the Board of Governors, or the regional Federal Reserve Banks. Articles may be reprinted, reproduced, published, distributed, displayed, and transmitted in their entirety if copyright notice, author name(s), and full citation are included. Abstracts, synopses, and other derivative works may be made only with prior written permission of the Federal Reserve Bank of St. Louis. 
dollars through these facilities, the Fed also lent billions to depository institutions (commercial banks, savings institutions, and credit unions) through its long-standing discount window programs and a Term Auction Facility (TAF) established in December 2007. 1 The Fed's aggressive response to the crisis has been heavily criticized, though the Fed's defenders contend that it was necessary and successful in helping the economy weather the worst financial crisis since the Great Depression. $\underline{2}$

This paper examines the Fed's lending to depository institutions (hereafter "banks") during the recent financial crisis, recession, and recovery. Some observers contend that the Fed lent inappropriately to weak or insolvent banks, or that its lending may have merely delayed the inevitable failures of many banks and perhaps increased losses to the Federal Deposit Insurance Corporation (FDIC) Deposit Insurance Fund. $\underline{3}$ The Federal Reserve Act specifies the terms under which the Fed is permitted to lend to banks. Section 142 of the Federal Deposit Insurance Corporation Improvement Act of 1991 (FDICIA) limits-but does not prohibit-Federal Reserve lending to undercapitalized or critically undercapitalized banks. With certain exceptions, FDICIA prohibits the Federal Reserve from lending to (i) any undercapitalized depository institution for more than 60 days in any 120-day period and (ii) any critically undercapitalized institution beyond the fifth day after the institution becomes critically undercapitalized. Using both public and nonpublic information, we examine instances in which the Fed provided loans through its discount window and TAF programs to undercapitalized and critically undercapitalized banks during the recent financial crisis, recession, and recovery. Our research finds no instances in which the Fed provided credit to an undercapitalized or critically undercapitalized bank for more than the maximum number of days specified in FDICIA.

This article also examines Federal Reserve lending to banks that subsequently failed during 2008-10. A principal motivation behind the provisions on lending to undercapitalized banks in FDICIA was the claim that Federal Reserve loans had merely forestalled inevitable bank failures during the 1980s, which may have increased losses to the FDIC's Deposit Insurance Fund when those banks were ultimately closed. Gilbert (1994) examined Fed lending to banks that failed during the 1980s. He found that loans were allocated to the banks with the greatest liquidity needs and that loans to banks that failed during 1985-91 were often concentrated near the time of failure. This article finds that, in contrast to the period 1985-91, few banks that failed during 2008-10 borrowed from the Fed in their last year of operation.

\section{FDICIA PROVISIONS ON LENDING TO UNDERCAPITALIZED BANKS}

The U.S. Congress enacted legislation in 1991 that mandated many changes in the way federal agencies supervise and regulate depository institutions. This legislation, FDICIA, was a response to the widespread collapse of the savings and loan industry and large number of bank failures during the 1980s. The mandates of the legislation were based on the view that government supervision of banks and savings and loan associations had performed poorly during the 1980s.

Federal Reserve lending to undercapitalized banks was one of many facets of the process of resolving failing banks addressed by FDICIA. Section 142 of FDICIA imposes limits on Federal Reserve lending to undercapitalized and critically undercapitalized banks. The act states that with certain exceptions, "no advances to any undercapitalized depository institution by any 


\section{Table 1}

\section{Federal Reserve Regulation A}

\section{§201.5 Limitations on availability and assessments}

(a) Lending to undercapitalized insured depository institutions. A Federal Reserve Bank may make or have outstanding advances to or discounts for a depository institution that it knows to be an undercapitalized insured depository institution, only:

(1) If, in any 120-day period, advances or discounts from any Federal Reserve Bank to that depository institution are not outstanding for more than 60 days during which the institution is an undercapitalized insured depository institution; or

(2) During the 60 calendar days after the receipt of a written certification from the chairman of the Board of Governors or the head of the appropriate federal banking agency that the borrowing depository institution is viable; or

(3) After consultation with the Board of Governors. In unusual circumstances, when prior consultation with the Board is not possible, a Federal Reserve Bank should consult with the Board as soon as possible after extending credit that requires consultation under this paragraph (a)(3).

(b) Lending to critically undercapitalized insured depository institutions. A Federal Reserve Bank may make or have outstanding advances to or discounts for a depository institution that it knows to be a critically undercapitalized insured depository institution only:

(1) During the 5-day period beginning on the date the institution became a critically undercapitalized insured depository institution; or

(2) After consultation with the Board of Governors. In unusual circumstances, when prior consultation with the Board is not possible, a Federal Reserve Bank should consult with the Board as soon as possible after extending credit that requires consultation under this paragraph (b)(2).

(c) Assessments. The Board of Governors will assess the Federal Reserve Banks for any amount that the Board pays to the FDIC due to any excess loss in accordance with section $10 \mathrm{~B}(\mathrm{~b})$ of the Federal Reserve Act. Each Federal Reserve Bank shall be assessed that portion of the amount that the Board of Governors pays to the FDIC that is attributable to an extension of credit by that Federal Reserve Bank, up to 1 percent of its capital as reported at the beginning of the calendar year in which the assessment is made. The Board of Governors will assess all of the Federal Reserve Banks for the remainder of the amount it pays to the FDIC in the ratio that the capital of each Federal Reserve Bank bears to the total capital of all Federal Reserve Banks at the beginning of the calendar year in which the assessment is made, provided, however, that if any assessment exceeds 50 percent of the total capital and surplus of all Federal Reserve Banks, whether to distribute the excess over such 50 percent shall be made at the discretion of the Board of Governors.

SOURCE: www.federalreserve.gov/bankinforeg/reglisting.htm.

Federal Reserve Bank...may be outstanding for more than 60 days in any 120 -day period." $\underline{4}$ Under FDICIA, the Fed is subject to financial liability if it provides credit to a critically undercapitalized bank beyond the fifth day after the bank becomes critically undercapitalized and the Deposit Insurance Fund incurs a loss greater than it would have incurred if the FDIC had liquidated the bank by the end of the five-day period. $\underline{5}$ Section 201.5 of Federal Reserve Regulation A, which is reproduced in Table 1, summarizes the limitations on extensions of Federal Reserve credit to undercapitalized and critically undercapitalized depository institutions and the possible assessments that could be levied on Federal Reserve Banks for any excess losses to the Deposit Insurance Fund arising from delay in liquidating a critically undercapitalized bank. FDICIA classifies depository institutions with capital ratios below specified levels or that have been assigned the lowest examination rating by their principal regulator as either undercapitalized or critically undercapitalized. Tables 2 through 4 provide information about the measures of capital and the ratios used to classify a depository institution as undercapitalized or critically undercapitalized. 


\section{Gilbert, Kliesen, Meyer, Wheelock}

\section{Table 2}

\section{Components of Capital Measures}

\section{Tier 1 capital}

- Common stockholder's equity.

- Non-cumulative perpetual preferred stock.

- Minority interests in the equity accounts of consolidated subsidiaries.

\section{Tier 2 capital}

- The allowance for loan and lease losses (up to a maximum of 1.25 percent of risk-weighted assets).

- Cumulative perpetual or long-term preferred stock.

- Hybrid capital instruments and mandatory convertible debt securities.

- Subordinated debt and intermediate-term preferred stock.

- Unrealized holding gains on equity securities.

- The amount of subordinated debt and intermediate-term preferred stock that a bank may count as Tier 2 capital cannot exceed 50 percent of its Tier 1 capital. In addition, these two components and any other limited-life capital instruments are discounted in Tier 2 computations as they approach maturity.

\section{Tier 3 capital}

- Allocated for market risk.

\section{Total capital}

- The sum of Tier 1, Tier 2, and Tier 3 capital.

SOURCE: Spong (2000, pp. 87-88).

\section{FEDERAL RESERVE PROGRAMS FOR LENDING TO BANKS DURING THE FINANCIAL CRISIS}

Provisions in FDICIA on lending to undercapitalized banks apply to all extensions of Federal Reserve credit to banks. The Fed's primary lending facility—-the discount window-has been in existence since the Fed was established in 1913. $\underline{6}$ Currently, the discount window consists of three programs: primary credit, secondary credit, and seasonal credit. Primary credit is a facility available to banks in generally sound financial condition. Secondary credit is available to banks that are not eligible for primary credit because they do not meet the standard of being in generally sound financial condition. The interest rate on secondary credit is higher than the discount rate on primary credit. The seasonal credit program offers loans to banks with recurring seasonal variation in liquidity demand-typically small banks that serve agriculture, tourism, or other seasonally oriented industries.

During the financial crisis, the Federal Reserve established a new facility-the Term Auction Facility (TAF) - to make term funds available to banks. The TAF was created in response to concerns that banks were reluctant to borrow from the discount window and, hence, that the window was not providing sufficient liquidity to alleviate the financial crisis. The Federal Reserve made 4,214 TAF loans to 411 borrowers. Total TAF loans outstanding peaked at $\$ 493$ billion on March 2, 2009. ${ }^{-}$The final TAF auction was held on April 8, 2010. Table 5 provides more detail about the discount window and TAF programs. 


\section{Table 3}

\section{Calculation of Risk-Weighted Assets Under Basel I}

\section{Category 1: Zero percent weight}

- Cash, including balances due from central banks in OECD countries.

- U.S. Treasury and government securities and claims unconditionally guaranteed by OECD governments.

Category 2: 20 percent weight

- Cash items in the process of collection.

- All claims on or guaranteed by U.S. depository institutions and banks in OECD countries.

- General obligation bonds of state and local governments.

- Portions of claims secured by U.S. government agency securities or OECD central governments that do not qualify for a zero percent weight.

- Loans and other claims conditionally guaranteed by U.S. government securities and other claims on U.S. governmentsponsored enterprises.

Off balance sheet:

- Short-term trade-related contingencies, such as commercial letters of credit.

\section{Category 3: 50 percent weight}

- Loans secured by first liens on 1- to 4-family residential property and certain multifamily residential properties.

- Certain privately issued mortgage-backed securities.

- Revenue bonds of state and local governments.

Off balance sheet:

- Performance bonds and performance-based standby letters of credit.

- Unused portions of commitments with original maturity over 1 year.

- Revolving underwriting facilities.

\section{Category 4: 100 percent weight}

- All loans and other claims on private obligators not placed in a lower risk category.

- Bank premises, fixed assets, and other real estate owned.

- Industrial development revenue bonds.

- Intangible assets and investment in unconsolidated subsidiaries, provided they are not deducted from capital.

Off balance sheet:

- Financial standby letters of credit.

- Sale and repurchase agreements.

- Asset sales with recourse.

- Forward agreements to purchase assets.

- Securities lent that place the bank at risk.

SOURCE: Spong (2000, pp. 89-90). 


\section{Table 4}

\section{Criteria for Classifying Bank Capitalization}

\begin{tabular}{|c|c|c|c|c|c|}
\hline Classification & $\begin{array}{l}\text { Total risk-based capital } \\
\text { as a percentage of } \\
\text { risk-weighted assets }\end{array}$ & & $\begin{array}{c}\text { Tier } 1 \text { capital } \\
\text { as a percentage of } \\
\text { risk-weighted assets }\end{array}$ & & $\begin{array}{c}\text { Tier-1 } \\
\text { leverage ratio }\end{array}$ \\
\hline Well capitalized & $10 \%$ or greater & AND & $6 \%$ or greater & AND & $5 \%$ or greater \\
\hline Adequately capitalized & $8 \%$ or greater & $A N D$ & $4 \%$ or greater & $A N D$ & $4 \%$ or greater \\
\hline Undercapitalized & Less than $8 \%$ & $O R$ & Less than $4 \%$ & OR & Less than $4 \%$ \\
\hline Significantly undercapitalized & Less than $6 \%$ & OR & Less than $3 \%$ & OR & Less than $3 \%$ \\
\hline
\end{tabular}

NOTE: In addition to meeting these criteria, a well-capitalized bank must also be free of any directive from its supervisor to maintain a specific capital level. A bank is classified as undercapitalized if it fails to meet any of the three measures for being classified as adequately capitalized. That is, if a bank meets only two of the three criteria for being classified as adequately capitalized, it is classified as undercapitalized. A bank is classified as undercapitalized for purposes of discount window loans if its federal supervisory agency rates the bank as CAMELS 5 or equivalent, irrespective of the levels of the three capital ratios derived from the accounting statements. A bank is classified as critically undercapitalized if its ratio of tangible equity to total assets is equal to or less than 2 percent.

SOURCE: Spong (2000, p. 91).

\section{Table 5}

\section{Federal Reserve Programs for Lending to Depository Institutions}

The discount window helps to relieve liquidity strains for individual depository institutions and for the banking system as a whole by providing a source of funding in time of need. Much of the statutory framework that governs lending to depository institutions is contained in section 10B of the Federal Reserve Act, as amended. The general policies that govern discount window lending are set forth in Regulation A. As described in more detail below, depository institutions have, since 2003, had access to three types of discount window credit_-primary credit, secondary credit, and seasonal credit. In December of 2007, the Federal Reserve introduced the Term Auction Facility (TAF), which provided credit to depository institutions through an auction mechanism. All regular discount window loans and TAF loans must be fully collateralized to the satisfaction of the lending Reserve Bank, with an appropriate haircut applied to the collateral; in other words, the value of the collateral must exceed the value of the loan. Information on collateral policies and interest rates charged for lending are discussed in the collateral and rate setting and risk management sections of this website.

\section{Primary credit}

Primary credit is a lending program available to depository institutions that are in generally sound financial condition. Because primary credit is available only to depository institutions in generally sound financial condition, it is generally provided with minimal administrative requirements; for example, there are essentially no usage restrictions on primary credit. Before the current financial crisis, primary credit was available on a very short-term basis, typically overnight, at a rate 100 basis points above the Federal Open Market Committee's (FOMC) target rate for federal funds. The primary credit facility helps provide an alternative source of funding if the market rate exceeds the primary credit rate, thereby limiting trading at rates significantly above the target rate.

The Federal Reserve implemented a number of important changes to the primary credit program as the financial crisis emerged. On August 17, 2007, to promote orderly market functioning, the Federal Reserve reduced the spread between the primary credit rate and the target federal funds rate to 50 basis points and began to allow the provision of primary credit for terms as long as 30 days. On March 16, 2008, to bolster market liquidity, the Federal Reserve further reduced the spread of the primary credit rate over the target federal funds rate to 25 basis points and increased the maximum maturity of primary credit loans to 90 days.

continued on next page 
Gilbert, Kliesen, Meyer, Wheelock

\section{Table 5, cont'd}

\section{Federal Reserve Programs for Lending to Depository Institutions}

In response to the improvement in financial conditions, on November 17, 2009, the Federal Reserve announced that the maximum maturity on primary credit loans would be reduced to 28 days effective January 14, 2010. In extending primary credit, Reserve Banks must judge that the borrower is likely to remain eligible for primary credit for the term of the loan. On February 18 , 2010, the Federal Reserve announced that typical maximum maturity on primary credit would be shortened to overnight, effective March 18, 2010. In addition, the Federal Reserve increased the spread between the primary credit rate and the top of the target range for the federal funds rate to 50 basis points, effective February 19, 2010. These changes represented further normalization of the Federal Reserve's lending facilities and did not signal any change in the outlook for the economy or for monetary policy. Detailed information is available on the discount window website.

Primary credit outstanding is reported in Table 1 of the H.4.1 statistical release. In addition, primary credit is included in "Other loans" in Tables 8 and 9 of that release.

\section{Secondary credit}

Secondary credit is available to depository institutions that are not eligible for primary credit. It is extended on a very short-term basis, typically overnight, at a rate 50 basis points above the primary credit rate. In contrast to primary credit, there are restrictions on the uses of secondary credit extensions. Secondary credit is available to meet backup liquidity needs when its use is consistent with a timely return by the borrower to a reliance on market sources of funding or the orderly resolution of a troubled institution. Secondary credit may not be used to fund an expansion of the borrower's assets. Moreover, the secondary credit program entails a higher level of Reserve Bank administration and oversight than the primary credit program. Reserve Banks typically apply higher haircuts on collateral pledged to secure secondary credit. In addition, the liquidity position of secondary credit borrowers is monitored closely, and the Federal Reserve typically is in close contact with the borrower's primary federal regulator. Detailed information is available on the discount window website.

Secondary credit outstanding is reported in Table 1 of the H.4.1 statistical release. In addition, secondary credit is included in "Other loans" in Tables 8 and 9 of that release.

\section{Seasonal credit}

The Federal Reserve's seasonal credit program assists small depository institutions in managing significant seasonal swings in their loans and deposits. Eligible depository institutions may borrow term funds from the discount window during their periods of seasonal need, enabling them to carry fewer liquid assets during the rest of the year and, thus, allow them to make more funds available for local lending. The interest rate applied to seasonal credit is a floating rate based on market rates.

Seasonal credit is available only to depository institutions that can demonstrate a clear pattern of recurring intra-yearly swings in funding needs. Eligible institutions are usually located in agricultural or tourist areas. To become eligible for seasonal credit, an institution must establish a seasonal qualification with its Reserve Bank. Detailed information is available on the discount window website.

Seasonal credit outstanding is reported in Table 1 of the H.4.1 statistical release. In addition, seasonal credit is included in "Other loans" in Tables 10 and 11 of that release.

\section{Term Auction Facility}

On December 12, 2007, the Federal Reserve created the TAF to improve depository institutions' access to term funding. The TAF provided credit through an auction mechanism to depository institutions in generally sound financial condition. The TAF offered 28-day and, beginning in August 2008, 84-day loans.

On September 24, 2009, the Federal Reserve announced that the TAF would be scaled back in response to continued improvements in financial market conditions. The auction amount for the 84-day auctions was reduced in late 2009 and the maturity dates of the 84-day auctions were adjusted over time to align with the maturity dates of the 28-day auctions. Subsequently, the auction amount for the remaining 28-day auctions was tapered, and the final TAF auction was held on March 8, 2010. Credit extended under the March 2010 auction matured on April 8, 2010. All TAF loans were fully collateralized to the satisfaction of the lending Reserve Bank, with an appropriate "haircut" applied to the value of the collateral and were repaid in full, with interest, in accordance with the terms of the facility.

SOURCE: www.federalreserve.gov/monetarypolicy/bst_lendingdepository.htm. 


\section{Figure 1}

\section{Primary Credit and Term Auction Facility Loans}

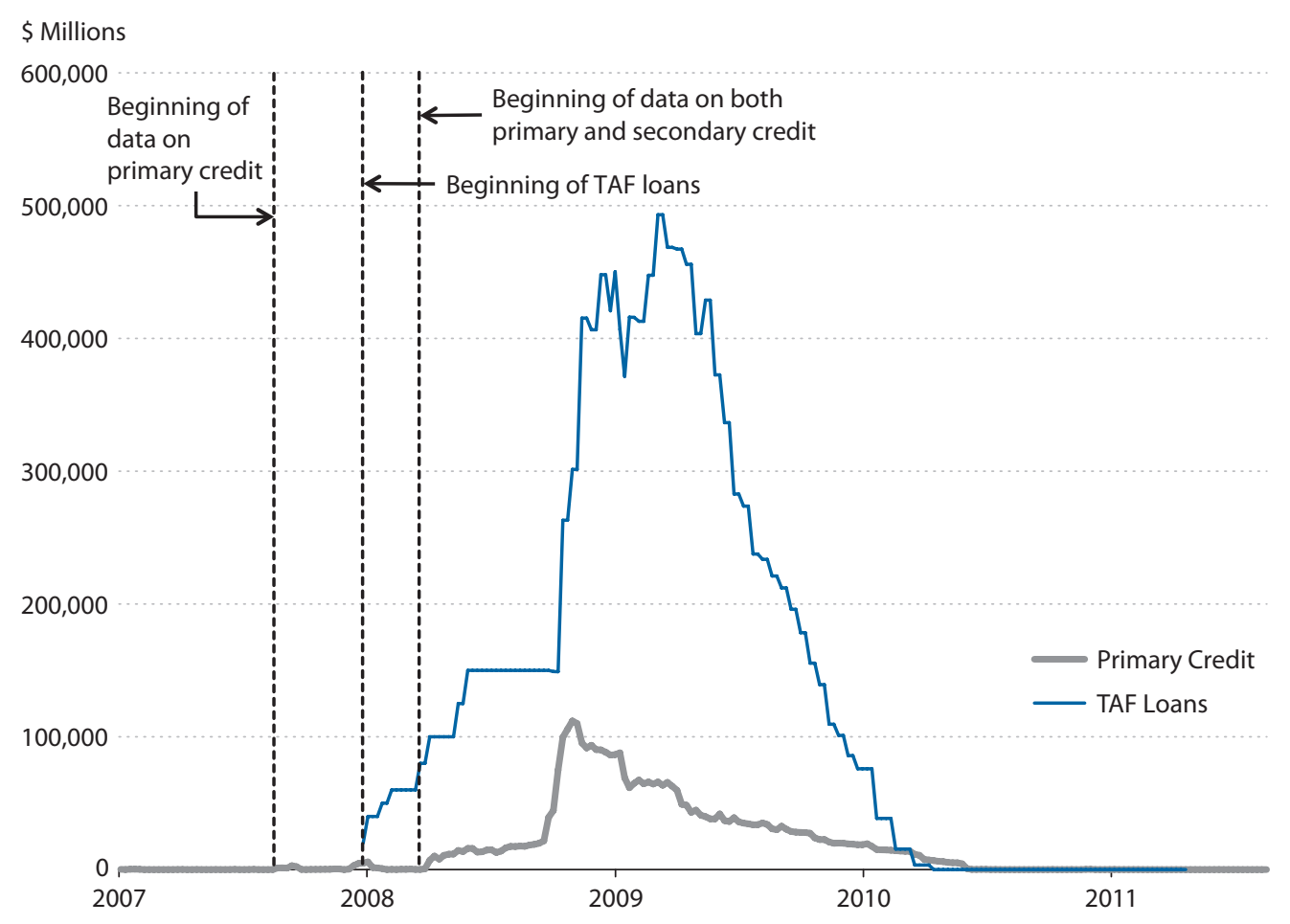

NOTE: Data are weekly.

Figures 1 and 2 illustrate the scope of Federal Reserve assistance to banks during the financial crisis through the discount window and the TAF program. Figure 1 plots weekly outstanding Federal Reserve credit for the primary credit and TAF programs, and Figure 2 plots similar totals for the secondary and seasonal credit programs. As these figures show, TAF loans accounted for the bulk of the Fed's assistance to depository institutions. By early 2009, outstanding TAF loans totaled nearly $\$ 500$ billion. By contrast, primary credit loans peaked in late 2008 at just over $\$ 100$ billion. Indeed, Figure 1 also shows that primary credit loans began to decline sharply, and the difference between TAF loans and primary credit loans increased sharply after the failure of Lehman Brothers in September 2008. Figure 2 shows that while secondary credit loans rose noticeably during the crisis, they peaked at only about $\$ 1$ billion in late 2009. Interestingly, the peak activity in secondary credit lending occurred when TAF and primary credit lending were declining rapidly.

We use data on Federal Reserve discount window loans to individual depository institutions that were released by the Federal Reserve in March 2011 in response to a Freedom of Information Act request and subsequent court ruling. The data include loans to individual institutions made between August 20, 2007, and March 1, 2010. Data from August 20, 2007, through March 13, 2008, are limited to primary credit borrowings, whereas data from March 14, 2008, through March 1, 2010, include both primary and secondary credit loans. However, for the latter period, 


\section{Figure 2}

\section{Secondary and Seasonal Credit Loans}

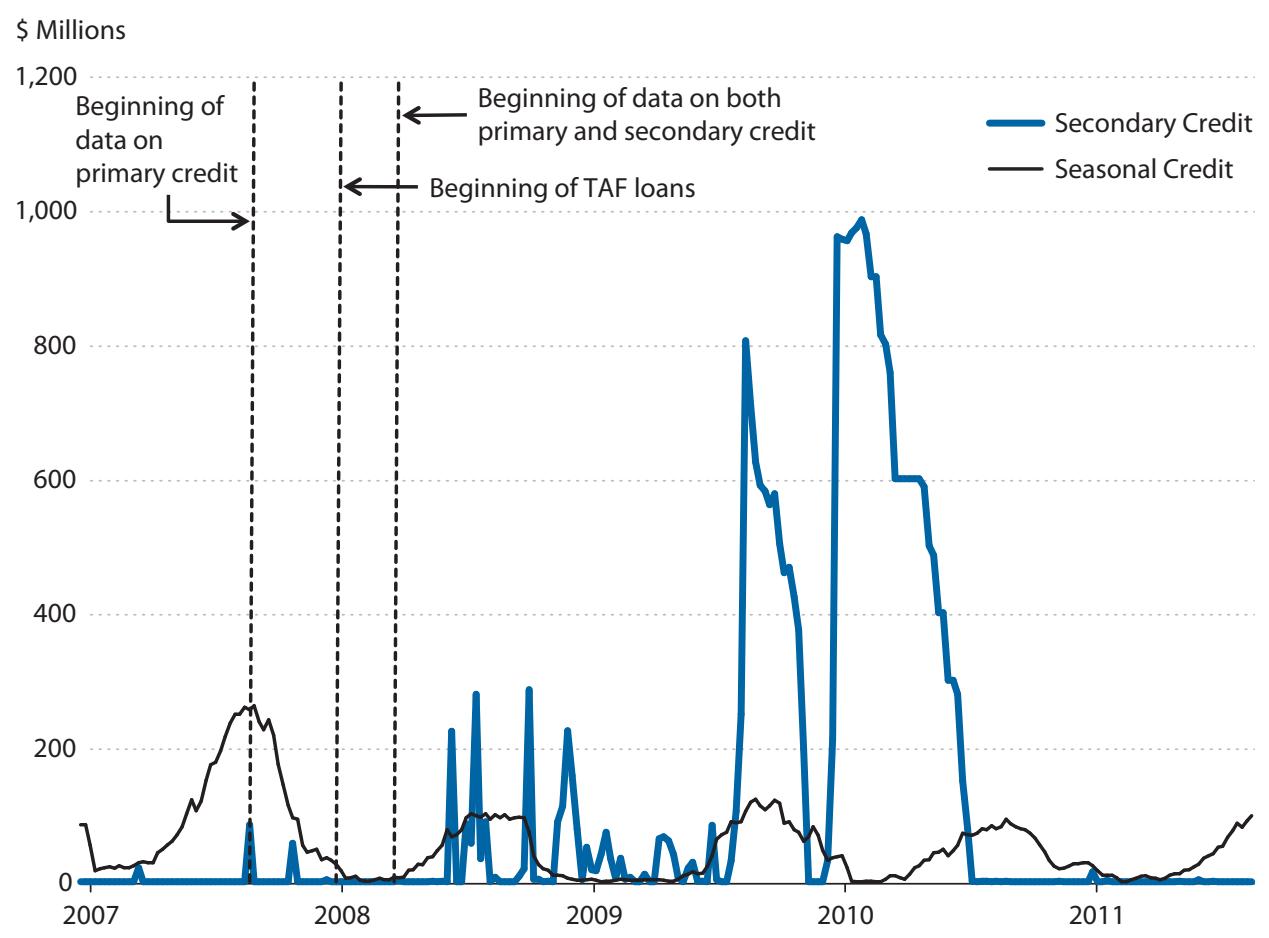

NOTE: Data are weekly.

the available data do not identify which loans were made under the primary credit program and which were secondary credit. Further, we do not include loans made under the seasonal credit program. This study uses data on all TAF loans made to individual depository institutions from December 20, 2007, through March 11, 2010.. Our data include information about TAF loans that were subsequently called by the Fed before their original maturity dates.

As shown in Figure 1, the large increases in primary credit during 2007-10 occurred after August 20, 2007, the first date for which we have data on loans to individual banks. In addition, primary credit had fallen to a relatively low level by March 1, 2010, the last date for which we have data on loans to individual banks. Most of the larger spikes in secondary credit in Figure 2 occurred between March 14, 2008, and March 1, 2010, the period for which our data on loans to individual banks include secondary credit. Almost no secondary credit loans were made before March 14, 2008, and hence the lack of data on secondary credit loans to individual institutions before that date is not an important problem for our study. In addition, seasonal credit, which was not included in the data available for this study, was not large during 2007-10.

The lending data released by the Federal Reserve in 2011 include some loans excluded from our study. First, we omit all loans to depository institutions other than those made under the discount window or TAF programs. These include loans in which depository institutions merely 
served as conduits under various programs established by the Federal Reserve during the financial crisis. The organizations that ultimately received the funds-not the conduit banks-were responsible for repaying the Federal Reserve. Hence, such loans are not relevant for our study. We also exclude loans to U.S. branches and agencies of foreign financial institutions because the Federal Reserve uses different metrics to determine their eligibility for credit. ${ }^{9}$ Similarly, we exclude loans to credit unions because the capital measures of credit unions differ from the regulatory capital ratios of commercial banks and thrift institutions. However, we found no instances when Federal Reserve credit was extended to an undercapitalized credit union, as reflected by the methods the Fed uses to identify undercapitalized credit unions.

\section{IDENTIFYING UNDERCAPITALIZED AND CRITICALLY UNDERCAPITALIZED BANKS}

Section 142 of FDICIA lists criteria for classifying banks as undercapitalized or critically undercapitalized and specifies the maximum length of time the Federal Reserve may lend to such institutions. These criteria include regulatory capital ratios and examination ratings assigned by bank supervisors. FDICIA authorizes bank regulators to define regulatory capital ratios based on information collected in the Reports of Condition and Income ("call reports") that banks file quarterly with regulators. Section 142 of FDICIA also requires regulators to consider a bank that has been assigned the lowest supervisory rating as undercapitalized for purposes of access to Federal Reserve credit, even if the bank would be considered adequately capitalized on the basis of regulatory capital ratios.

A definitive determination of whether the Federal Reserve restricted the length of time it made loans to undercapitalized and critically undercapitalized banks to the limits set in FDICIA requires information about when Fed officials learned about the condition of banks that requested loans. Much of the information about a bank's condition that is available to Fed lending officers is derived from quarterly call reports and reports of supervisory examinations. However, call reports are sometimes revised and on-site examinations, especially of distressed banks, can take some time to complete. Hence, Fed lending officers typically do not have up-to-theminute information about a borrowing bank's condition. Call report information usually becomes available within 30 days after the end of a quarter (banks are required to file their call reports within 30 days of the end of a quarter). Data on the regulatory capital ratios of banks are derived from these reports. Gunther and Moore (2000) examine the frequency of revisions to call reports, focusing on one item in the call reports: provision for loan losses, which is an expense item. That study finds that regulators are more likely to require banks with the most severe asset-quality problems, as reflected in the ratio of nonperforming loans to total assets, to increase their provision for loan losses. This can lead to revisions of previously filed call reports. In their sample, Gunther and Moore (2000) find that among banks examined in the first quarter of a given year, almost 10 percent of those with the worst asset quality were required to increase their provision for loan losses as reported in the call report for the fourth quarter of the prior year. Their findings also indicate that revisions to call reports are especially relevant for undercapitalized banks.

Because call reports are sometimes revised, especially in the case of financially troubled banks, we use an internal Federal Reserve database - the Prompt Corrective Action Database 
(PCAD) - which provides information about the data on regulatory capital positions of banks that were available to Federal Reserve lending officers at the time loans were made. The PCAD is updated regularly with information on the current regulatory capital ratios of banks and is used by bank supervisors for taking the corrective actions required by FDICIA.

We augment the data on regulatory capital ratios with information on supervisory examination dates and ratings. Bank examinations are performed by state and federal agencies that supervise banks. Supervisors assign ratings from 1 (best) to 5 (worst) for each of the following facets of bank operations: capital adequacy, asset quality, management, earnings, liquidity, and sensitivity to market risk; in addition, supervisors assign a composite score from 1 to 5 (known as the CAMELS composite rating). FDICIA classifies all banks with a composite CAMELS rating of 5 as undercapitalized regardless of their current capital ratios.

Examination ratings are not released publicly but are made available both to the examined institution and to supervisory authorities, including Federal Reserve lending officers. The precise dates on which Fed officials are informed of the ratings assigned for individual bank exams are not systematically recorded, however, and hence we consider alternative dates that bound the actual reporting dates. Specifically, we use both the exam close date, which is the date when the supervisory staff finish their examination, and the report disposition date, which is the date the examination was finalized and mailed to institution management or the date an internal memo on examination findings was completed and sent to the Board of Governors. Supervisory agencies may not have determined the CAMELS ratings they assign to banks as of the exam close dates, but they will have assigned CAMELS ratings to banks by the report disposition dates. Federal Reserve credit officers use all available information in evaluating requests from banks for loans, including any information on examination ratings made available prior to the report disposition date. However, in most instances, the report disposition date is likely the most relevant date for counting the number of days that a bank received Federal Reserve credit while undercapitalized or rated CAMELS 5.

To estimate the number of days that Federal Reserve credit was extended to undercapitalized banks, we use two alternative criteria for classifying banks as undercapitalized as follows:

(i) banks that were undercapitalized on the basis of regulatory capital ratios from the PCAD database or the close dates of exams for which banks are rated CAMELS 5 or

(ii) banks that were undercapitalized on the basis of regulatory capital ratios from the PCAD database or the report disposition dates of exams for which banks are rated CAMELS 5.

With the one exception discussed below, we find that the choice of examination date has no material impact on our findings about the length of time that undercapitalized banks borrowed from the Fed during the period covered by our data.

\section{DID THE FED COMPLY WITH THE FDICIA LIMITS ON LENDING TO UNDERCAPITALIZED BANKS?}

Table 6 presents information on the number of days that Federal Reserve credit was extended to undercapitalized banks based on exam close and report disposition dates. For undercapital- 


\section{Table 6}

\section{Banks with Outstanding Discount Window or TAF Loans While Undercapitalized According to PCAD Information or CAMELS 5 Rating}

\begin{tabular}{lcc} 
& \multicolumn{2}{c}{ No. of banks with outstanding loans } \\
\cline { 2 - 3 } No. of days with loan & 39 & Based on report disposition dates \\
\hline $0-5$ & $6 a s e d$ on exam close dates & 32 \\
$6-10$ & 2 & 3 \\
$11-25$ & 5 & 4 \\
$26-59$ & 1 & 0 \\
60 or more & 53 & 45 \\
Total & & 6 \\
NOTE: Data used to construct these tables include adjustments for repayment of TAF loans prior to original maturity dates.
\end{tabular}

ized banks that received Federal Reserve credit for more than 60 days in total, we investigate whether the Fed extended credit to the bank for more than 60 days during any 120-day period, the maximum permitted under FDICIA. For undercapitalized banks that received credit for 60 days or less in total, investigation of whether the bank received credit for more than 60 days in a 120 -day period is unnecessary.

Using exam close dates, we find that 53 banks borrowed from the Fed while undercapitalized. More than half of these banks borrowed for 5 days or less while undercapitalized, but one bank borrowed for 72 days within a 120-day period while undercapitalized. However, further investigation revealed that the FDICIA limit on the number of days that the Fed may lend to an undercapitalized bank was not violated in this instance. The bank was classified as undercapitalized on the basis of an examination on which the bank was assigned a composite CAMELS rating of 5 (the bank had been rated 2 at its previous exam). However, the new CAMELS rating was not considered final on the closing date of the exam, and the report disposition date on which the rating was considered final did not occur until five months after the exam closing date. The bank's primary regulator informed the lending Reserve Bank of the pending examination rating approximately three months after the exam closing date, by which time the bank was no longer borrowing from the Fed. No additional credit was extended to the bank after the date on which Reserve Bank officials were informed of the pending rating.

As shown in Table 6, if we use exam report disposition dates for determining when banks became undercapitalized, 45 banks borrowed from the Fed while undercapitalized, but none of them for more than 60 days. Using either the exam closing or report disposition dates, we find that most of the banks that borrowed from the Fed while undercapitalized did so for five days or less.

We identified only one instance in which the Fed extended credit to a bank that was identified as critically undercapitalized in the PCAD database. However, further investigation revealed that this bank was not undercapitalized when it received Federal Reserve credit. The bank was undercapitalized on September 30, 2008, as reflected in its third-quarter 2008 call report. The bank received additional capital during the fourth quarter of 2008, which made the bank well 


\section{Table 7}

\section{Distribution of Banks that Borrowed from the Federal Reserve While Undercapitalized: Asset Size}

\begin{tabular}{lcc} 
& \multicolumn{2}{c}{ No. of banks } \\
\cline { 2 - 3 } Total assets & Based on exam close dates & Based on report disposition dates \\
\hline Greater than $\$ 10$ billion & 1 & 1 \\
\$1 billion to $\$ 10$ billion & 14 & 14 \\
\$300 million to $\$ 1$ billion & 20 & 19 \\
\$100 million to $\$ 300$ million & 13 & 3 \\
Less than $\$ 100$ million & 5 & 45 \\
Total & 53 & 3 \\
NOTE: Asset size is measured as of September 30, 2007. & &
\end{tabular}

\section{Table 8}

Distribution of Banks that Borrowed from the Federal Reserve While Undercapitalized: Charter Type

\begin{tabular}{lcc} 
& \multicolumn{2}{c}{ No. of banks } \\
\cline { 2 - 3 } Charter type & Based on exam close dates & Based on report disposition dates \\
\hline National banks & 13 & 11 \\
State member banks & 7 & 5 \\
Nonmember banks* & 30 & 26 \\
Federal savings banks & 1 & 1 \\
State savings bank & 1 & 1 \\
Savings and loan associations & 1 & 1 \\
Total & 53 & 45 \\
NOTE: Charter type as of September 30, 2007. *Banks that are not members of the Federal Reserve System. &
\end{tabular}

capitalized. However, the PCAD database continued to indicate that the bank was critically undercapitalized until January 30, 2009, when the database first indicated the bank's wellcapitalized position as reflected in its fourth-quarter 2008 call report. Although the PCAD database had not been updated to reflect the borrowing bank's well-capitalized status when the Fed extended credit to the bank on January 28 and 29, 2009, the bank was in fact well capitalized at that time and, hence, there was no violation of FDICIA.

Another way to put the results in Table 6 into perspective is to compare the number of banks that borrowed from the Fed while undercapitalized with the total number of banks that became undercapitalized during the period for which we have data on loans to individual banks. Between September 30, 2007, and March 31, 2010, 625 banks and thrifts were rated either CAMELS 5 or became undercapitalized based on regulatory capital ratios. Thus, regardless of whether we use exam close or report disposition dates as the basis for classifying banks as undercapitalized, we find that only a small percentage of undercapitalized banks during this period borrowed from the Fed at any time while undercapitalized. 


\section{Gilbert, Kliesen, Meyer, Wheelock}

Table 7 provides information on the asset size of the banks identified in Table 6 as borrowing from the Fed while undercapitalized. Assets are measured at the beginning of the period for which we have data on lending to individual banks. One of these banks had assets in excess of $\$ 10$ billion, and a few had assets less than $\$ 100$ million.

Table 8 provides information on the charter class of the banks in Table 6 . A few banks changed their charter class during the period covered by our data. The information in Table 8 is based on charter class at the beginning of the period. Most borrowers were commercial banks, and among those, the largest group consisted of state banks that were not members of the Federal Reserve System.

\section{FEDERAL RESERVE LOANS TO FREQUENT BORROWERS}

The evidence reported in Table 6 does not prove that the provisions in FDICIA caused the Fed to restrict lending to undercapitalized banks. As noted previously, over 90 percent of banks that became undercapitalized during the period for which we have data did not borrow from the Fed while undercapitalized. In addition, 44 of the 53 banks that borrowed from the Fed while undercapitalized based on exam close dates borrowed for fewer than 60 days over the entire period covered by our data, including days when they were adequately capitalized. For the 45 banks that borrowed from the Fed while undercapitalized based on the report disposition dates, 37 borrowed from the Fed for fewer than 60 days during the entire period covered by our data, including days when they were adequately capitalized. Thus, the observations in Table 6 on the number of days that banks borrowed from the Fed while undercapitalized may reflect a general reluctance of banks to rely on Federal Reserve credit rather than restrictions imposed by the Fed in FDICIA or for other reasons.

We may learn more about the impact of FDICIA on lending to undercapitalized banks by focusing on banks that borrowed frequently from the Fed before they became undercapitalized. The eight banks listed in Table 9 relied heavily on the Fed as a consistent source of credit, borrowing almost every day for at least three months just before becoming undercapitalized based on the exam close date. Becoming undercapitalized may have limited their access to credit from sources other than the Fed even more than in the period before they became undercapitalized. And yet the periods over which these banks borrowed from the Fed while undercapitalized were much shorter than the periods over which they borrowed before they became undercapitalized. To illustrate, the bank identified as number 8 in Table 9 borrowed from the Fed on 126 days over a period of 136 days -93 percent of the time-just before it became undercapitalized

but for only 2 days after it became undercapitalized. This suggests that the Fed promptly cut off access to credit for this bank after it became undercapitalized, even though the bank had relied on credit from the Fed almost continuously over the preceding four months.

Table 10 provides comparable information for seven banks that borrowed frequently before becoming undercapitalized based on the report disposition dates. The borrowing patterns shown in Tables 9 and 10 illustrate that banks that borrowed frequently from the Fed in the three months before they became undercapitalized borrowed much less frequently after they were classified as undercapitalized. This suggests that the Fed followed the intent of Congress in limiting access to credit by undercapitalized banks. 


\section{Table 9}

\section{Fed Lending to Frequent Borrowers Before and After They Became Undercapitalized*}

\begin{tabular}{llc} 
Bank number & \multicolumn{1}{c}{$\begin{array}{c}\text { Borrowing just before } \\
\text { becoming undercapitalized }\end{array}$} & $\begin{array}{c}\text { Days of borrowing after } \\
\text { becoming undercapitalized }\end{array}$ \\
\hline 1 & Borrowed 325 days in a period of 403 days: $81 \%$ & 72 \\
2 & Borrowed 137 days in a period of 147 days: $93 \%$ & 37 \\
3 & Borrowed 117 days in a period of 122 days: $96 \%$ & 27 \\
4 & Borrowed 295 days in a period of 302 days: $98 \%$ & 19 \\
5 & Borrowed 140 days in a period of 140 days: $100 \%$ & 7 \\
6 & Borrowed 169 days in a period of 176 days: $96 \%$ & 7 \\
7 & Borrowed 103 days in a period of 105 days: $98 \%$ & 2 \\
8 & Borrowed 126 days in a period of 136 days: $93 \%$ & \\
NOTE: *Undercapitalized banks identified based on exam close date. &
\end{tabular}

\section{Table 10}

\section{Fed Lending to Frequent Borrowers Before and After They Became Undercapitalized*}

\begin{tabular}{llc} 
Bank number & $\begin{array}{c}\text { Borrowing just before } \\
\text { becoming undercapitalized }\end{array}$ & $\begin{array}{c}\text { Days of borrowing after } \\
\text { becoming undercapitalized }\end{array}$ \\
\hline 1 & Borrowed 137 days in a period of 147 days: $93 \%$ & 37 \\
2 & Borrowed 117 days in a period of 122 days: $96 \%$ & 27 \\
3 & Borrowed 295 days in a period of 302 days: $98 \%$ & 19 \\
4 & Borrowed 140 days in a period of 140 days: $100 \%$ & 8 \\
5 & Borrowed 169 days in a period of 176 days: $96 \%$ & 7 \\
6 & Borrowed 103 days in a period of 105 days: $98 \%$ & 7 \\
7 & Borrowed 126 days in a period of 136 days: $93 \%$ & 2 \\
NOTE: *Undercapitalized banks identified based on report disposition date. &
\end{tabular}

\section{FEDERAL RESERVE LENDING TO BANKS THAT SUBSEQUENTLY FAILED}

The provisions on Fed lending to undercapitalized banks in FDICIA are based on the idea that loans to undercapitalized banks may increase losses incurred by the FDIC deposit insurance funds. This section examines Federal Reserve lending to banks that failed during the recent recession. In particular, we compare the extent of lending to banks that subsequently failed during 2008-10 with lending to banks that failed during 1985-90, a period of numerous bank failures preceding the enactment of FDICIA in 1991.

Failed banks often face rapid reductions in their deposit liabilities just before failure. The discount window is one source of funds for troubled banks that face liquidity pressures generated by rapid decreases in deposits and the closing of alternative sources of funds. Gilbert (1995) found that of the banks that failed during the years 1985-90, those with the most rapid declines 
Gilbert, Kliesen, Meyer, Wheelock

\section{Table 11}

\section{Distribution of Failed Banks by Borrowings from the Federal Reserve in Their Last Year}

\begin{tabular}{lcccc} 
Failure period & No. of banks & $\begin{array}{c}\text { Borrowed in their } \\
\text { last } \mathbf{5 2} \text { weeks } \\
\text { No. (\%) }\end{array}$ & $\begin{array}{c}\text { Borrowed in their } \\
\text { last 13 weeks } \\
\text { No. (\%) }\end{array}$ & $\begin{array}{c}\text { Borrowed in at least 26 } \\
\text { of their last } \mathbf{5 2} \text { weeks } \\
\text { No. (\%) }\end{array}$ \\
\hline $\begin{array}{l}1985-90 \\
2008-10\end{array}$ & $185(58.2)$ & $154(48.4)$ & $28(8.8)$ \\
NOTE: Data for 2008-10 are for August 20, 2008, through March 1, 2010.
\end{tabular}

in deposit liabilities during their last year were more likely to borrow from the Federal Reserve and were likely to borrow larger amounts than other failed banks.

Federal Reserve Chairman Ben Bernanke (2011) has noted that the Federal Reserve has occasionally provided loans to assist with the orderly resolution of failing banks:

In the handful of instances when discount window loans were extended to troubled institutions, it was in consultation with the Federal Deposit Insurance Corporation to facilitate a least-cost resolution; in these instances, also, the Federal Reserve was fully repaid.

Because it takes time for the FDIC to determine the least costly method of resolving a failing bank, Federal Reserve loans to troubled banks potentially can assist in facilitating orderly resolutions of failing banks and avoiding market and service disruptions arising from sudden liquidation. However, reference in the Chairman's statement to "the handful of instances" indicates that Fed loans to facilitate orderly resolutions are not common. There is no official list of cases in which the Federal Reserve made loans to failing banks in consultation with the FDIC for purposes of facilitating orderly resolutions. Data available on discount window loans to individual banks during the period August 20, 2007, through March 1, 2010, confirm, however, that Fed loans to facilitate orderly resolutions were not common. Of the 177 banks that failed during the period from August 20, 2008, through March 1, 2010, only 23 borrowed from the Federal Reserve at any time during their last 13 weeks (Table 11).

Even among the banks that borrowed from the Federal Reserve while undercapitalized, few were borrowing in the period just before failure. Of the 53 banks identified in Table 6 that borrowed from the Federal Reserve while undercapitalized based on exam close dates, 28 failed within the period for which we have data on loans to individual banks. Only 12 of these 28 banks borrowed from the Federal Reserve within one month of their failure dates. There were gaps of several months between their last discount window loans and failure dates for most of the other 16 banks that borrowed while undercapitalized and failed by March 1, 2010. These 16 banks used sources of funds other than the discount window for managing any unusual liquidity pressures near their failure dates. Of the 45 banks identified in Table 6 that borrowed from the Federal Reserve while undercapitalized based on report disposition dates, 27 failed within the period for which we have data on loans to individual banks. Only 11 of these 27 banks borrowed from the Federal Reserve within one month of their failure dates.

Next we compare Fed lending to banks that failed during the recent financial crisis with lending during the years 1985-90, based on observations in Gilbert (1994). To make this com- 


\section{Figure 3}

\section{Commercial Bank and Savings Institution Failures (January 2007-December 2011)}

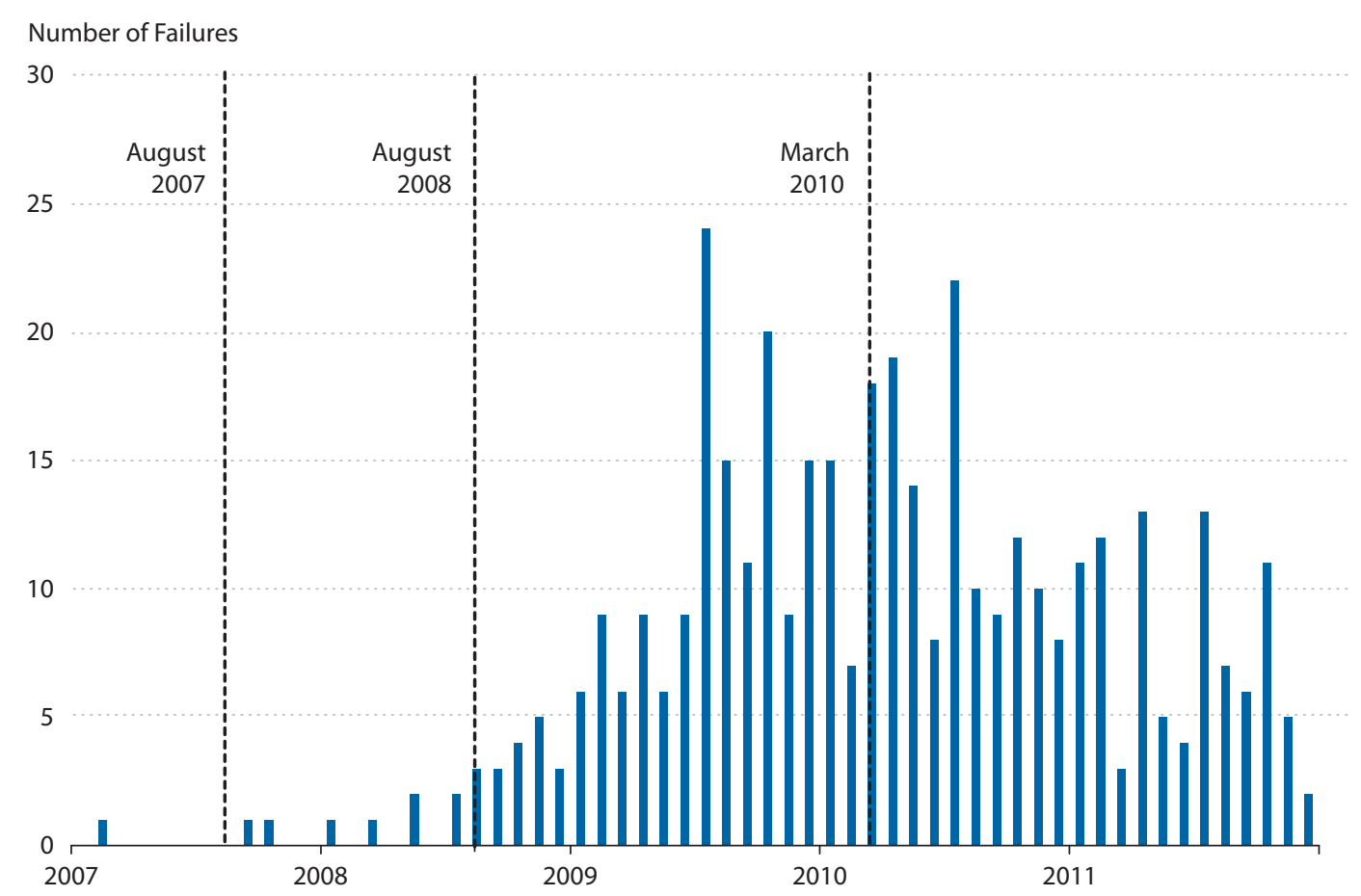

parison, we require data on Fed loans to individual institutions for at least one year prior to their failure dates. Since data on Fed loans are available for August 20, 2007, through March 1, 2010, our sample of failed banks includes those that failed during the period August 20, 2008, through March 1, 2010. For this sample we impose no restriction on asset size, unlike Gilbert (1994), whose study was based on a sample of 318 banks that excluded the smallest strata of banks that were not required to file weekly reports on their deposit liabilities. Our sample of failed banks includes 148 commercial banks, 27 savings banks, and 2 savings and loan associations, for a total of 177 banks. Figure 3 shows the total number of bank failures (including failures of commercial banks and savings institutions) by month for January 2007 through December 2011. Data on discount window lending are available for the period from August 2007 through March 2010. Relatively few bank failures occurred prior to August 2008.

Table 11 compares the frequency of Fed lending to banks that failed during 2008-10 with lending to banks that failed in 1985-90, as reported in Gilbert (1994, Table 1). For the banks that failed during 2008-10, data on Fed lending include both discount window and TAF loans. The information reported in the table accounts for TAF loans that were repaid to the Fed before their original maturity dates.

The percentages of failed banks that borrowed from the Fed during their last 52 weeks and their last 13 weeks were substantially smaller during 2008-10 than during 1985-90. Of the 177 


\section{Table 12}

\section{Distribution of Failed Banks by the Size of Their Borrowings Relative to Their Average Total Deposits Over Their Last 13 Weeks}

\begin{tabular}{|c|c|c|c|c|}
\hline \multirow[b]{3}{*}{ Range of ratios of borrowings to total deposits } & \multicolumn{4}{|c|}{$\begin{array}{l}\text { Sum of borrowings divided by the sum of total deposits } \\
\text { over the following periods ending on failure dates }\end{array}$} \\
\hline & \multicolumn{2}{|c|}{$1985-90$} & \multicolumn{2}{|c|}{ 2008-10 } \\
\hline & No. of banks & Cumulative \% & No. of banks & Cumulative \% \\
\hline 0 & 164 & 51.57 & 153 & 87.43 \\
\hline $0.0<x \leq 0.001$ & 28 & 60.38 & 11 & 93.71 \\
\hline $0.001<x \leq 0.005$ & 29 & 69.50 & 4 & 96.00 \\
\hline $0.005<x \leq<0.010$ & 23 & 76.73 & 4 & 98.29 \\
\hline $0.010<x \leq 0.020$ & 20 & 83.02 & 1 & 98.86 \\
\hline $0.020<x \leq 0.050$ & 25 & 90.88 & 0 & 98.86 \\
\hline $0.050<x \leq 0.100$ & 14 & 95.28 & 0 & 98.86 \\
\hline $0.100<x \leq 0.200$ & 11 & 98.74 & 2 & 100.00 \\
\hline $0.200<x$ & 4 & 100.00 & 0 & 100.00 \\
\hline
\end{tabular}

NOTE: Data for 2008-10 are for August 20, 2008, through March 1, 2010. Deposit data are missing for 2 of the 177 banks that failed over this period. One of the missing banks borrowed during its last 13 weeks and the other missing bank did not borrow.

banks that failed during the period from August 20, 2008, through March 1, 2010, only 23 borrowed from the Federal Reserve at any time during their last 13 weeks. The last column of Table 11 presents information on failed banks that borrowed frequently from the Fed throughout their last year. Four banks ( 2.3 percent) borrowed during 26 or more of their last 52 weeks during 2008-10, whereas 28 banks in the sample ( 8.8 percent) borrowed during 26 or more of their last 52 weeks during 1985-90. Table 11 indicates that while the Fed made loans frequently to a small number of banks that failed during 2008-10, as a group these banks relied less on the Fed for credit during their last year than did the banks that failed during 1985-90.

Tables 12 through 14 compare the dollar amount of Fed lending to banks relative to their total deposits over their last 13,26, and 52 weeks for banks that failed during the two periods, using the format of Table 3 in Gilbert (1994). For both periods we include days on which banks did not borrow in calculating average borrowings. Data on deposits for 1985-90 were derived from weekly reports by the banks to the Fed on their total deposit liabilities. Comparable weekly deposit data are not available for 2008-10. For those years, we use quarterly call report data to approximate average total deposits over the last 13,26 , and 52 weeks of a failed bank's existence. $\underline{10}$

Table 12 compares ratios of average borrowings to total deposits over the last 13 weeks for failed banks. Banks that failed during 2008-10 tended to rely less on the Fed for credit in the weeks just before their failures than did banks that failed during 1985-90. Among banks that failed during 2008-10, 87 percent did not borrow from the Fed during their last 13 weeks, compared with 52 percent for the banks that failed during 1985-90. Borrowings were less than onehalf of 1 percent of average total deposits for 96 percent of the banks that failed during 2008-10, compared with 70 percent for the banks that failed during 1985-90. Two of the banks that failed 


\section{Table 13}

Distribution of Failed Banks by the Size of Their Borrowings Relative to Their Average Total Deposits Over Their Last 26 Weeks

\begin{tabular}{|c|c|c|c|c|}
\hline \multirow[b]{3}{*}{ Range of ratios of borrowings to total deposits } & \multicolumn{4}{|c|}{$\begin{array}{l}\text { Sum of borrowings divided by the sum of total deposits } \\
\text { over the following periods ending on failure dates }\end{array}$} \\
\hline & \multicolumn{2}{|c|}{$1985-90$} & \multicolumn{2}{|c|}{ 2008-10 } \\
\hline & No. of banks & Cumulative \% & No. of banks & Cumulative \% \\
\hline 0 & 149 & 46.86 & 142 & 80.23 \\
\hline $0.000<x \leq 0.001$ & 54 & 63.84 & 24 & 93.79 \\
\hline $0.001<x \leq 0.005$ & 29 & 72.96 & 5 & 96.61 \\
\hline $0.005<x \leq 0.010$ & 23 & 80.19 & 2 & 97.74 \\
\hline $0.010<x \leq 0.020$ & 22 & 87.11 & 1 & 98.31 \\
\hline $0.020<x \leq 0.050$ & 24 & 94.65 & 0 & 98.31 \\
\hline $0.050<x \leq 0.100$ & 10 & 97.80 & 1 & 98.87 \\
\hline $0.100<x \leq 0.200$ & 5 & 99.37 & 1 & 99.44 \\
\hline $0.200<x$ & 2 & 100.00 & 1 & 100.00 \\
\hline
\end{tabular}

NOTE: Data for 2008-10 are for August 20, 2008, through March 1, 2010.

\section{Table 14}

Distribution of Failed Banks by the Size of Their Borrowings Relative to Their Average Total Deposits Over Their Last 52 Weeks

\begin{tabular}{|c|c|c|c|c|}
\hline \multirow[b]{3}{*}{ Range of ratios of borrowings to total deposits } & \multicolumn{4}{|c|}{$\begin{array}{l}\text { Sum of borrowings divided by the sum of total deposits } \\
\text { over the following periods ending on failure dates }\end{array}$} \\
\hline & \multicolumn{2}{|c|}{$1985-90$} & \multicolumn{2}{|c|}{ 2008-10 } \\
\hline & No. of banks & Cumulative \% & No. of banks & Cumulative $\%$ \\
\hline 0 & 133 & 41.82 & 119 & 67.23 \\
\hline $0.000<x \leq 0.001$ & 65 & 62.26 & 39 & 89.27 \\
\hline $0.001<x \leq 0.005$ & 52 & 78.62 & 9 & 94.35 \\
\hline $0.005<x \leq 0.010$ & 21 & 85.11 & 4 & 96.61 \\
\hline $0.010<x \leq 0.020$ & 23 & 92.45 & 2 & 97.74 \\
\hline $0.020<x \leq 0.050$ & 15 & 97.17 & 1 & 98.31 \\
\hline $0.050<x \leq 0.100$ & 6 & 99.06 & 1 & 98.87 \\
\hline $0.100<x \leq 0.200$ & 2 & 99.69 & 1 & 99.44 \\
\hline $0.200<x$ & 1 & 100.00 & 1 & 100.00 \\
\hline
\end{tabular}




\section{Gilbert, Kliesen, Meyer, Wheelock}

during 2008-10, however, had average borrowings over their last 13 weeks that were between 10 percent and 20 percent of their total deposits.

The pattern shown in Table 13 is similar to that in Table 12, indicating that banks that failed during 2008-10 relied less on Federal Reserve loans over their last 26 weeks than banks that failed during 1985-90. A few banks that failed during 2008-10, however, relied heavily on credit from the Fed during their last 26 weeks. Average borrowings were between 10 percent and 20 percent of average total deposits for one bank and exceeded 20 percent for another bank. The contrast between the two periods was similar for average borrowings relative to total deposits over the last 52 weeks before failure (Table 14). As a group, banks that failed during 2008-10 relied less on Federal Reserve credit during their last 52 weeks than did banks that failed during 1985-90. Comparisons of the patterns of Fed lending to failed banks during their last year are consistent with the conclusion that the provisions in FDICIA on lending to undercapitalized banks reduced the frequency and amount of lending to banks that failed during 2008-10 relative to such lending during 1985-90.

\section{CONCLUSION}

The Federal Deposit Insurance Corporation Improvement Act of 1991 (FDICIA) was, among other things, intended to limit the access of financially troubled banks to Federal Reserve credit and thereby help minimize losses incurred by federal deposit insurance funds. This article investigates the effectiveness of FDICIA by studying Federal Reserve lending to commercial banks and other depository institutions during the recent financial crisis, recession, and subsequent period of economic recovery. We address two principal questions, which are motivated by press reports and other commentary about Federal Reserve lending during the crisis: (i) Did the Fed violate either the letter or spirit of FDICIA by lending to undercapitalized banks? (ii) Did Federal Reserve lending constitute a large fraction of the deposit liabilities of banks that failed during their last year prior to failure?

Our research finds no evidence that the Fed ever knowingly lent to an undercapitalized bank for more than 60 days during the period between August 2007 and March 2010. In addition, the Fed never knowingly extended credit to a critically undercapitalized bank during that period. Hence, Fed lending to undercapitalized banks remained within the limits set in FDICIA. Moreover, in most cases, Federal Reserve credit was extended for considerably fewer days than permitted by FDICIA. Furthermore, compared with patterns of Fed lending during 1985-90, we find that few banks that failed during 2008-10 borrowed from the Fed during their last year prior to failure, and only a small number of banks had outstanding Fed loans when they failed. As a group, the banks that failed during the 2008-10 period relied less on the Federal Reserve as a source of credit during their last 52 weeks than did the banks that failed during 1985-90. Of course, it is impossible to know whether the enactment of FDICIA accounts for differences in Federal Reserve lending practices during the recent financial crisis and recovery and the previous period of financial distress in the 1980s. However, it does seem clear that Federal Reserve lending to depository institutions during the recent episode was consistent with the congressional intent of FDICIA. 


\section{NOTES}

1 For information about the specific programs established by the Fed in response to the financial crisis, see the Board of Governors website (www.federalreserve.gov/monetarypolicy/bst_crisisresponse.htm). The Federal Reserve Bank of St. Louis provides a timeline of crisis events and government action in response to the crisis (http://timeline.stlouisfed.org/).

2 Criticisms of aspects of the Fed's response to the crisis include those by Buiter (2009), Meltzer (2009), and Poole (2009). For responses to these and other criticisms, see Bernanke (2009, 2010), Madigan (2009), and Nelson (2011).

$\underline{3}$ For examples, see Applebaum and McGinty (2011) and Ivry, Keoun, and Kuntz (2011).

4 The limitation does not apply if the head of the appropriate banking agency or the Chairman of the Federal Reserve Board certifies to the Federal Reserve Bank that a depository institution is viable.

$\underline{5}$ The Fed's liability may not exceed the lesser of (i) any loss exceeding the loss that the FDIC would have incurred if it had liquidated the critically undercapitalized bank within five days of becoming critically undercapitalized and (ii) the interest earned by the Fed on advances to the bank beyond the first five days of becoming critically undercapitalized. The text of FDICIA is available from the Federal Reserve Bank of St. Louis website (http://fraser.stlouisfed.org/publication-series/?id=415).

6 See Bordo and Wheelock (2011) on what the Fed's founders sought to achieve by establishing the discount window, shortcomings with the mechanism that became apparent during the Great Depression, and subsequent reforms.

$\underline{7}$ Government Accountability Office (2011, p. 228). The General Accountability Office identified 416 unique names of TAF borrowers. We identified 411 unique depository institutions that received TAF loans, according to data provided by the Federal Reserve Board (www.federalreserve.gov/newsevents/reform taf.htm).

8 These data are available on the Board of Governors' website (www.federalreserve.gov/newsevents/reform_taf.htm).

9 The rating systems used for foreign banking organizations are described in Federal Reserve Supervisory Letters 96-36 and 00-14 (www.federalreserve.gov/boarddocs/srletters/1996/sr9627.htm and www.federalreserve.gov/boarddocs/srletters/ 2000/SR0014.HTM).

10 We estimated the average deposits of a failed bank over its last 13 weeks as the average of its total deposits in the two quarters directly before the bank's failure date. For example, if a bank failed in July 2009, total deposits correspond to the average of its total deposits for 2009:Q1 (March 31) and 2009:Q2 (June 30). The estimate of total deposits for a failed bank over its last 26 weeks is the average of its total deposits over the two quarters before failure. If a bank failed in July 2009, the estimate of total deposits in the second quarter before failure would be the average of the total deposits for 2008:Q4 (December 31) and 2009:Q1 (March 31). We estimated the total deposits of a failed bank over its last 52 weeks as its average of total deposits in the last four quarters before its failure. We estimated total deposits in the third quarter before failure as the average of total deposits for the third and fourth quarters before the bank's failure. If a bank failed in July 2009, the estimate of total deposits in the third quarter before its failure would be the average of the total deposits for 2008:Q3 (September 30) and 2008:Q4 (December 31). We estimated total deposits in the fourth quarter before failure as the average of the total deposits for the fourth and fifth quarters before the bank's failure. If a bank failed in July 2009, the estimate of total deposits in the fourth quarter before failure would be the average of the total deposits for 2008:Q2 (June 30) and 2008:Q3 (September 30).

\section{REFERENCES}

Applebaum, Binyamin and McGivney, Jo Craven. “Fed Help Kept Banks Afloat, Until It Didn't." New York Times, April 4, 2011.

Bernanke, Ben S. "Reflections on a Year of Crisis." Remarks at the Federal Reserve Bank of Kansas City's Annual Economic Symposium on Financial Stability and Macroeconomic Policy, Jackson Hole, Wyoming, August 21, 2009; www.federalreserve.gov/newsevents/speech/bernanke20090821a.htm.

Bernanke, Ben S. “Economic Challenges: Past, Present, and Future." Remarks at the Dallas Regional Chamber, Dallas, Texas, April 7, 2010; www.federalreserve.gov/newsevents/speech/20100407a.htm.

Bernanke, Ben S. "Correction of Recent Press Reports Regarding Federal Reserve Emergency Lending During the Financial Crisis." Letter to the Senate Banking Committee, U.S. Congress, December 6, 2011; www.federalreserve.gov/generalinfo/foia/emergency-lending-financial-crisis-20111206.pdf.

Bordo, Michael D. and Wheelock, David C. "The Promise and Performance of the Federal Reserve as Lender of Last Resort 1914-1933." Federal Reserve Bank of St. Louis Working Paper No. 2010-036B, January 2011; http://research.stlouisfed.org/wp/2010/2010-036.pdf.

Buiter, Willem. "The Fed's Moral Hazard Maximising Strategy." FT.com/maverecon, March 6, 2009; http://blogs.ft.com/maverecon/2009/03/the-feds-moral-hazard-maximising-stragegy/. 


\section{Gilbert, Kliesen, Meyer, Wheelock}

Gilbert, R. Alton. "Federal Reserve Lending to Banks that Failed: Implications for the Bank Insurance Fund." Federal Reserve Bank of St. Louis Review, January/February 1994, 76(1), pp. 3-18;

http://research.stlouisfed.org/publications/review/94/01/Lending_Jan_Feb1994.pdf.

Gilbert, R. Alton. "Determinants of Federal Reserve Lending to Failed Banks." Journal of Economics and Business, December 1995, 47(5), pp. 397-408.

Government Accountability Office. “Federal Reserve System: Opportunities Exist to Strengthen Policies and Processes for Managing Emergency Assistance." Report No. GAO-11-696, July 2011; www.gao.gov/new.items/d11696.pdf.

Gunther, Jeffery W. and Moore, Robert R. “Financial Statements and Reality: Do Troubled Banks Tell All?” Federal Reserve Bank of Dallas Economic and Financial Review, Third Quarter 2000, pp. 30-35; www.dallasfed.org/research/efr/2000/efr0003c.pdf.

Ivry, Bob; Keoun, Bradley and Kuntz, Phil. "Secret Fed Loans Gave Banks \$13 Billion Undisclosed to Congress." Bloomberg Markets Magazine, November 28, 2011;

www.bloomberg.com/news/2011-11-28/secret-fed-loans-undisclosed-to-congress-gave-banks-13-billion-in-income.html.

Madigan, Brian F. "Bagehot's Dictum in Practice: Formulating and Implementing Policies to Combat the Financial Crisis." Remarks at the Federal Reserve Bank of Kansas City's Annual Economic Symposium on Financial Stability and Macroeconomic Policy, Jackson Hole, Wyoming, August 21, 2009; www.federalreserve.gov/newsevents/speech/madigan20090821a.htm.

Meltzer, Allan H. "Regulatory Reform and the Federal Reserve." Testimony before the Subcommittee on Monetary Policy, House Committee on Financial Services, July 9, 2009; www.house.gov/apps/list/hearing/financialsvcs dem/meltzer testimony.pdf.

Nelson, Edward. "Friedman's Monetary Economics in Practice." Finance and Economics Discussion Series 2011-26. Divisions of Research and Statistics and Monetary Affairs, Board of Governors of the Federal Reserve System, Washington, DC, 2011; www.federalreserve.gov/pubs/feds/2011/201126/201126pap.pdf.

Poole, William. "The Bernanke Question." Cato Institute: Commentary, July 28, 2009; www.cato.org/publications/commentary/bernanke-question.

Spong, Kenneth. Banking Regulation: Its Purposes, Implementation, and Effects. Fifth Edition. Kansas City, MO: Federal Reserve Bank of Kansas City, 2000; www.kc.frb.org/publicat/bankingregulation/RegsBook2000.pdf. 


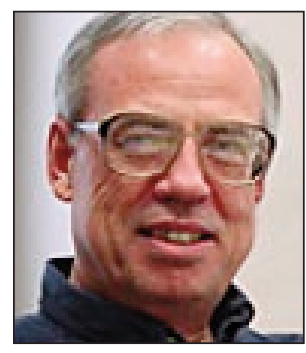

\section{R. Alton Gilbert}

Economist emeritus, Federal Reserve Bank of St. Louis

http://research.stlouisfed.org/econ/gilbert/

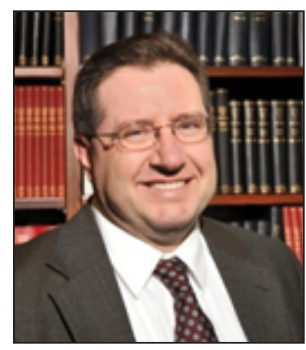

\section{Kevin L. Kliesen}

Business economist for the Supervisory Policy and Risk Analysis Unit, Federal Reserve Bank of St. Louis

http://research.stlouisfed.org/econ/kliesen/kkwp.html

\section{Research Focus}

Kevin Kliesen's research focuses on the analysis of macroeconomic conditions, the effects of energy prices on the economy, labor productivity, and fiscal policy; he also provides reports on economic and business conditions to assist the Bank president and Board of Directors.

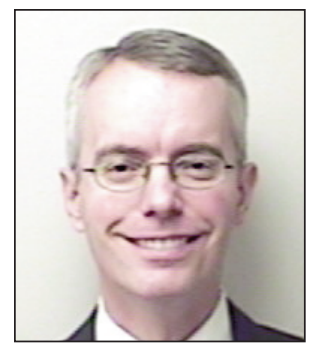

\section{Research Focus}

\section{Andrew P. Meyer}

Senior economist in the Banking Supervision and Regulation Division,

Federal Reserve Bank of St. Louis

Andy Meyer's research focuses mainly on community bank safety and soundness issues.

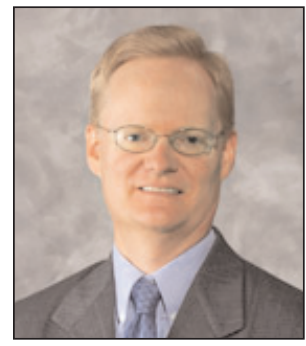

\section{Research Focus}

\section{David C. Wheelock}

Vice president and deputy director of research, Federal Reserve Bank of St. Louis

http://research.stlouisfed.org/econ/wheelock/

Dave Wheelock's research focuses on U.S. financial and monetary history, banking, and monetary policy. 